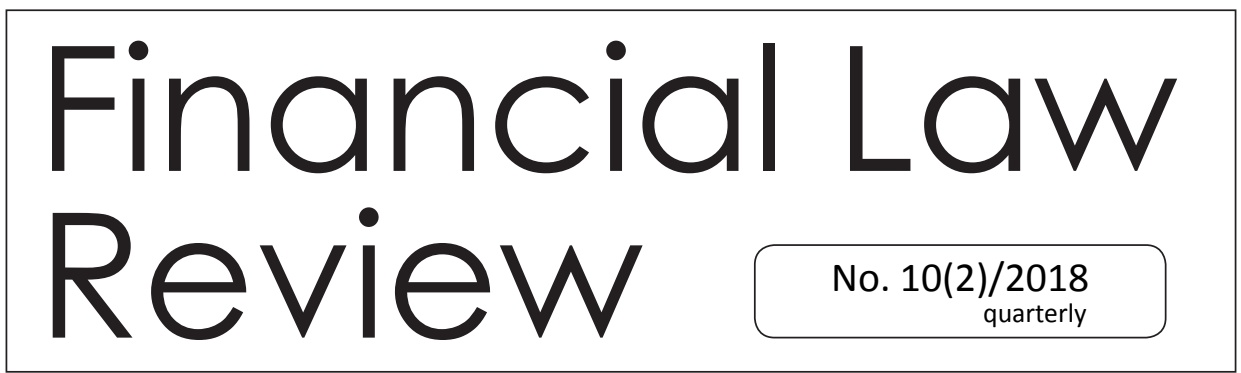

UNIVERSITY OF GDAŃSK • MASARYK UNIVERSITY • PAVEL JOZEF ŠAFÁRIK UNIVERSITY • UNIVERSITY OF VORONEZH http://www.ejournals.eu $\bullet$ http://czasopisma.bg.ug.edu.pl

\title{
FISCAL RULES IN POLAND AND THEIR EFFECTIVENESS (CHOSENLEGAL AND ECONOMIC ISSEUS) KRYSTYNA NIZIOE*
}

\begin{abstract}
In the paper effectiveness of the fiscal rules in Poland isanalysed. The main purpose of the Polish fiscal rules is to limit the public debt. Therefore, the paper also analyses the amount of public debt in Poland. The main aim of the contribution is to confirm the hypothesis that the fiscal rules established in the Polish financial law were effective in limiting the public debt. The paper uses such scientific methods as analysis of economic and legal literature, and statistic data connected with the amount of public debt in Poland.
\end{abstract}

\section{Key words}

fiscal rules; government policy and regulation; public finance; law and economics.

JEL Classification: G38, H5, K19.

\footnotetext{
* Assocciate Professor for Financial and Tax Law, Department of Public Economic Law, Faculty of Lawand Administration, Szczecin University, Poland. The author specializes in tax law, finance law and economic analysis of law. She is the author of 3 books and more than 30 reviewed articles in journals and monographs. She is a member of Information and Organization Centre for the Research on the Public Finances and Tax Law in the Countries of Central and Eastern Europe. Contact email: krystyna.niziol@usz.edu.pl
} 


\section{Introduction}

The problem of public debthas become more significant after the financial crisis in Europe. Sovereign debt crisisespeciallyhas led to a situation in which normative tools, which are meant tolimit the increase of public debt and deficit of the general government sector institutions, are of substantial importance.

The instruments of limiting public debt are fiscal rules, which are examples of the so called economization of law. The fiscal rules are established in the European Union (hereinafter EU) financial law and also in Polish financial law1. Moreover, fiscal rules became an important instrument of fiscal consolidation in the EU Member States. It should be stressed that fiscal rules concern both sub-sectorsof the Polish public finance sector (i. e. government sector and local government sector). It should strengthen their effectiveness in limiting public debt which is connected with the entire finance sector. According to Polish financial law, the public debt includes the debt of local government units.

In the paper effectiveness of the fiscal rules in Poland is analysed. The main purpose of the Polish fiscal rules is to limit the public debt. Therefore, the paper also analyses the amount of public debt in Poland. The main aim of the contribution is to confirm the hypothesis that the fiscal rules established in the Polish financial lawwere effective in limiting the public debt.The paper uses such scientific methodsasanalysis of economic and legal literature, and statistic data connected with the amount of public debt in Poland.

\subsection{Fiscal rules - general characteristics}

The instruments which are used to limit the public debt or budget (or public) deficit are fiscal rules. A fiscal rule is defined as permanent limitation of fiscal policy, usually defined in the form of synthetic total index (i.e.admissible) of fiscal result (budget) (Kopits, Symansky, 1998: 2). The aim of fiscal rules is the limitation of increase of defined economic values above established limit (e.g. public debt, public deficit, public expenses). That is why fiscal rules can be used as the instrument of fiscal consolidation. Literature provides traits which an optimal fiscal rule shouldposses in order to be effective in praxis. The above mentioned criteria refer to fiscal rules of supranational nature (Buiter, 2003: 6-8). Anyway, after the sovereign debt crisis in the year 2008 more and more EU Member States either introduced fiscal rules to their national regulations or modified existing rules in order to slow down the growth of public debt and deficit (Niziol, 2013: 11).

Fiscal rules (or numerical fiscal rules) are usuallyexamined in economic literature. 
Moreover, fiscal rules were established in the constitutions of manyEU Member States (e.g. Germany, Spain). It shows that fiscal rules have double nature, both economic and legal. It leads to theconclusion that the economic category such as fiscal rules has alsobecome the legal instrument of limiting the amount of public debt, budget deficit or public expenses. That is why fiscal rules are a good example of economization of law.

Fiscal rules are classified basing on different criteria. At present one can distinguish fiscal rules of supranational character (fiscal criteria concerning deficit of general government sector and public debt) and national fiscal rule (in particular EU countries). Fiscal rules can alsobe classified as: quantity rules (based on the numerical aim) and quality ones (concerning budget procedure), rules concerning determined economic category, e.g. budget expenses, budget deficit, public debt, rules defined at the fiscal central and local level. Fiscal rules in a given EU country are usually determined both at the fiscal central and local level. A similar solution was applied in the Polish financial law, which standardized both fiscal rules concerning public debt (includingliabilities of the whole sector of public finances and also units of local authorities) and limit of debt referring to respective units of local authorities (Nizioł, 2013: passim).

Two fiscal rules of supranational character were standardized in the EU financial law. These are fiscal convergence criteria concerning public debt and public deficit. They are bound with the so called procedure of excessive deficit defined in the Article 126 of the Treaty of Functioning of the European Union (hereafter TFU). The requirements of budget discipline are as follows. Firstly, the ratio of planned or real budget deficit to the GDP ${ }^{2}$ should not exceed 3\% GDP, unless: the ratio decreases considerably, is stable and reaches the level close to reference value, exceeding reference value is exceptional and temporary and the ratio remains close to reference value. Secondly, the ratio of public debt-to-the-GDP should not exceed $60 \%$ of the GDP unless: the ratio decreases sufficiently and approaches reference value in satisfactory pace (TFU, Art. 126).

Table 1 shows the selected criteria for the division of fiscal rules.

In economic literature the elements of an optimal fiscal rule were shown. An optimal fiscal rule should be simple, easy for verification, maintain financial liquidity of public authorities, should not determine optimal size of public sector, should enable functioning of automatic stabilizers of economic situation and should not encourage to use tools of pro-cyclical interaction, should have long-

\footnotetext{
GDP means Gross Domestic Product.
} 
Table 1. The selected criteria for the division of fiscal rules

\begin{tabular}{|l|l|}
\hline \multicolumn{1}{|c|}{ Criteria } & \multicolumn{1}{c|}{ Rule type } \\
\hline Geographic & $\begin{array}{l}\text { International (supranational) } \\
\text { National }\end{array}$ \\
\hline Subject & $\begin{array}{l}\text { Balance (deficit) } \\
\text { Expenditures (total, current, capital) } \\
\text { Debt (liabilities) } \\
\text { Revenues }\end{array}$ \\
\hline Subjective & $\begin{array}{l}\text { Concerning the whole public sector (according to the adopted sector rule) } \\
\text { Concerning government budget } \\
\text { Concerning local government budget } \\
\text { Concerning selected sector units }\end{array}$ \\
\hline Legal & $\begin{array}{l}\text { Of the international (including EU) legal basis } \\
\text { Of the constitutional basis } \\
\text { Of the statutory basis } \\
\text { Of other legal basis }\end{array}$ \\
\hline Structural & $\begin{array}{l}\text { Concerning the nominal values of the indicated budget items } \\
\text { Concerning of the selected budget items to items overall } \\
\text { Concerning the relation to GDP } \\
\text { Concerning the relation to other macroeconomic and budget quantities }\end{array}$ \\
\hline
\end{tabular}

Source: Marchewka-Bartkowiak, 2016: 29.

term character, take into consideration diverse situation of Economic and Monetary Union of the EU, should have universal character (i.e. be used at the level of economies of respective European Monetary Union countries, and the whole Eurozone, be credible, be used unbiased and consistent) (Buiter, 2003: 6-8). One of the conditions of efficiency of a fiscal rule is the aim defined numerically,i.e. as the limitation of national fiscal policy in the form of general budget results such as expenses, loans, debt. Moreover, these rules should alsobe connected with procedural reforms of budget institutions, which are conducive to responsible fiscal behavior. Empirical researches confirm that the connection of these both kinds of rules supports maintaining budget discipline effectively (Buti, Guidice, 2002:3-6). Other requirements which should be met by a fiscal rule are precise determination of a budget index to which a given rule refers; providing it with a respective legal importance by standardizing it in the constitution, or an act; clear premises of the fiscal rule, which is understood by the public; determination of sanctions against not obeying it and the body responsible for imposing them; choice of a rule in accordance with the chosen economic and financial strategy of a country in the medium and long term perspective (Marchewka-Bartkowiak, 2010: 3).Anyway, the possibility of practical application of an optimal fiscal rule in Eurozone is limited for the reasons such as lack of simplicity or the possibility 
of adjusting the fiscal rule to the current political objectives (Krajewski, Markiewicz, Piłat, 2015: 404).

Fiscal rules have also become the instrument of fiscal consolidation. Fiscal consolidation of public finances is connected with the notion of fiscal adjustment. Periods of fiscal adjustments are based on observed changes of budget deficits in relation to GDP. Nevertheless, these criteria are contractual, because fiscal consolidation can also be determined for every year in which there is positive change of budget balance (Gupta, Clements, Baldacci, Mulas-Granados, 2002: 22) 3 .Fiscal rules "if properly applied, can be an effective tool for fiscal consolidation. The effectiveness of the rules is largely dependent on the practical possibility of their non-compliance ("by-pass"). One can specify the conditions under which fiscal rules should demonstrate higher efficiency." (Działo, 2012a: 76).

Fiscal consolidation - in the wide meaning - aims at decreasing amount of deficit as well as amount of the public debt (OECD, 2011). Issues concerning fiscal consolidation have become a very crucial problem at the times of economic crisis, which has led to debt crisis in many countries. However, the increase of the public debt isnot only a consequence of the economic crisis, but also of fiscal policy of a given country, especially the amount of expenses for health care and retirement pensions (Sutherland, Hoeller, Merola, 2012: 11-13).

Social and economic consequences of the economic crisis initiated a number of changes in the EU financial law including ones connected with consolidation of public finances. One should pay attention to changes which aim at strengthening coordination of economic policies in the EU which are made on the way of strengthening of the preventive and corrective part of the Stability and Growth Pact, strengthening budget supervision in the Eurozone, as well as introduction of new frames of institutional, macroeconomic supervision. Execution of new requirements concerning preventive and corrective part of Stability and Growth Pact by the European Monetary Union countries has been strengthened, through introduction of new sanctions included in frames of the budget supervision, i.e. duty of placing on deposit equal to $0.2 \%$ GDP, which could turn into fine (Regulation no. 1176/2011).Moreover new frames of macroeconomic supervision were introduced. The procedure of excessive disturbance of balance within which a warning mechanism is to be worked out, basing on the identification of disturbances of macroeconomic balance established on the basis of tables of macroeco-

3 Decrease of basic structural deficit by at least $1.5 \%$ GDP within a year, or at least $1.2 \%$ GDP within two years can set as an example of expansive fiscal consolidation (Bukowski, Kowal, Lewandowski, Zawistowski, 2005: 131-133). 
nomic indexes created for every EU country with indication of alarm thresholds is to be a new tool of this supervision. A sanction (reaching $0.1 \%$ GDP in the previous year) was also introduced in this case, if disciplinary actions which are undertaken earlier are not effective and successful. Introduction of the so called European Semester, which aims at assuring closer coordination of economic procedures and achieving stable convergence of economic results of the Member States, constitutes subsequent change. The Council carries out multi-sided supervision for coordination of economic policy in accordance with the aims and requirements foreseen in the TFU, which includes such actions as an assessment of stability program, or program of convergence of member stated, supervision which aims at prevention of disturbance of macroeconomic balance and its correction within the frames of the European Semester (Regulation no. 1174/2011).

Guidelines for EU Member States, which are taken into consideration by these countries in shaping their economic, budget, employment policies before making crucial decisions concerning national budget for subsequent years, are made after the assessment of these programs. If a Member state does not comply with the above mentioned guidelines it is exposedto defined sanctions, such as warning of Commission issued on the basis of Art. 121/4 of TFU (Regulation no. 1466/97, Art. 2a). These are not all changes, which aim at counteracting the debt crisis in the EU countries. Fiscal rules are an instrument which was created for it. It is one of the changes in the EU financial law in introduction of these rules along with the rules of supranational character concerning public debt and deficit, also at the national level in EU countries (Regulation no. 1466/97, Art. 2a).

In literature theadvantages and disadvantages of fiscal ruleswere described. The advantages of fiscal rules include arule which helps reduce tendency for the deficit and improve the situation of public finance sector. The fiscal rules also have some disadvantages, among others, some of the rules would reduce flexibility of fiscal policy, e.g. the budget deficit rules and public debt rules (Działo, 2012a: 70-71).

It must alsobe stressed that in practice the optimal fiscal rule does not exist. The fiscal rules usually combine advantages and disadvantages. Therefore, it is very important to select fiscal rules which would implement the given objectiveseffectively. That is why the effective fiscal rule should be, among others, properly defined, characterized by simplicity and transparency, flexible, the most suitable for the objective it serves, supported by a consensus (Działo, 2012b: 227-228). 


\subsection{The Polish fiscal rules - classification and effectiveness}

In Polish financial law different kinds of fiscal rules (concerning public finance sector $^{4}$ and local government sector)were established.Moreover, Poland has to respect the above mentioned supranational fiscal rule (i.e.EU), among others, deficit criterion and EU debt criterion.

There are multiple definitions of public debt in economic literature. In Polish finance literature public debt was defined in many ways. For example, C. Kosikowski defines public debt as liabilities of the entities belonging to the public sector connected with financing of the deficit of the public sector and the budget deficit (Kosikowski, 2001: 14). The legal definition of the public debt is "the state public debt" (the Constitution of Poland, Art. 216/5). The definition of state public debt is related to, among others, a way of calculating and financing of public debt (PFA, Art. 73/1). The public debt is calculated as the nominal value of the liabilities of public sector entities after the elimination of mutual obligations between individuals in the sector (after consolidation). In the EU financial law the term 'public debt' may be defined in connection with excessive deficit procedure (EDP). The excessive deficit procedure is applied to all EU Member States 5 . It was established by Article 126 of TFU.

The main aim of Polish fiscal rules is to limit the public debt (and also the public expenditures). Today the public debt is a significant problem in the EU countries. The reason for this is that public debt causes a lot of economic and financial problems. Incurring public debt inter alia: we receive financial means at once and the cost of servicing public debt is spread in time ${ }^{6}$, but it usually leads to increase of tax rate, creditors can choose the amount of obligations they want to buy, creditors can choose the time of buying obligations, transfers budget incomes form tax to the creditors - in form of debt servicing costs, debt burden for the next generations, causes decrease of global spending power, public debt can be an instrument of changing the structure of economy (e.g. financing of capital spending) (Rybarski, 1935: 362-264; Gaudemet, Moliner, 2000: 358-363).

Table 2 shows fiscal rules forced in Poland.

4 The Polish public finance sector is the equivalent of general government sector in EU financial law.

5 The pinpointing of this procedure was stated in the Stability and Growth Pact applied by all EU Member states. Though its restrictive part does not refer to states which are not members of the Economic and Monetary Union, being subject to derogation in that respect (Oręziak, 2005: 59-66).

6 For example, in PFA there is a legal definition of expenditures for servicing the State Treasury debt. Expenditures for servicing the State Treasury debt shall in particular consist of state budget expenditures due to interest and discount on treasury securities, interest on drawn credits and loans as well as payments related to guarantees granted by the State Treasury. 
Table 2. Fiscal rules forced in Poland

\begin{tabular}{|c|c|c|c|c|}
\hline Rule Subject & Structure & Rule Formula & Subject & \begin{tabular}{|l} 
Legal Entry \\
\end{tabular} \\
\hline \multirow[t]{4}{*}{$\begin{array}{l}\text { The Balance } \\
\text { Rule }\end{array}$} & Deficit criterion & $3 \%$ of GDP & $\begin{array}{l}\text { General govern- } \\
\text { ment sector }\end{array}$ & EU \\
\hline & $\begin{array}{l}\text { Structural } \\
\text { balance rule } \\
(\mathrm{MTO})\end{array}$ & $\begin{array}{l}\text { The medium-term } \\
\text { fiscal objective i.e. } \\
\text { target structural } \\
\text { outcome of the gen- } \\
\text { eral government } \\
\text { sector stands at -1\% } \\
\text { GDP }\end{array}$ & $\begin{array}{l}\text { General govern- } \\
\text { ment sector }\end{array}$ & EU \\
\hline & $\begin{array}{l}\text { Balance offset- } \\
\text { ting rule }\end{array}$ & $\begin{array}{l}\text { General govern- } \\
\text { ment's balance must } \\
\text { be offset or in sur- } \\
\text { plus }\end{array}$ & $\begin{array}{l}\text { General govern- } \\
\text { ment sector }\end{array}$ & EU \\
\hline & $\begin{array}{l}\text { Local govern- } \\
\text { ment's current } \\
\text { budget offset- } \\
\text { ting rule }\end{array}$ & $\begin{array}{l}\text { The planned cur- } \\
\text { rent expenditures } \\
\text { must not exceed } \\
\text { the planned current } \\
\text { revenues plus the } \\
\text { budget surplus of the } \\
\text { previous years and } \\
\text { free resources }\end{array}$ & $\begin{array}{l}\text { Local govern- } \\
\text { ment sector }\end{array}$ & National \\
\hline \multirow[t]{3}{*}{ The Debt Rule } & $\begin{array}{l}\text { EU debt crite- } \\
\text { rion }\end{array}$ & $60 \%$ of $\mathrm{PKB}$ & $\begin{array}{l}\text { General govern- } \\
\text { ment sector }\end{array}$ & EU \\
\hline & $\begin{array}{l}\text { Relation of pub- } \\
\text { lic debt to GDP }\end{array}$ & $\begin{array}{l}\text { It is prohibited to } \\
\text { take out loans or } \\
\text { provide financial } \\
\text { guarantees resulting } \\
\text { in government pub- } \\
\text { lic debt exceeding } \\
3 / 5 \text { of annual GDP }\end{array}$ & $\begin{array}{l}\text { Public finance } \\
\text { sector }\end{array}$ & National \\
\hline & $\begin{array}{l}\text { Prudential } \\
\text { thresholds of } \\
\text { public debt }\end{array}$ & $\begin{array}{l}\text { Limiting the maxi- } \\
\text { mum level of public } \\
\text { debt in relation to } \\
\text { GDP to between } 55 \\
\text { and } 60 \% \text {; } \\
\text { Introducing reme- } \\
\text { dial procedure, } \\
\text { The threshold of } \\
48 \% \text { and } 43 \% \text { GDP is } \\
\text { linked to corrective } \\
\text { measures in the sta- } \\
\text { bilising expenditure } \\
\text { rule }\end{array}$ & $\begin{array}{l}\text { Public finance } \\
\text { sector }\end{array}$ & National \\
\hline
\end{tabular}




\begin{tabular}{|c|c|c|c|c|}
\hline & $\begin{array}{l}\text { Restrictions in } \\
\text { debt-serviced } \\
\text { local govern- } \\
\text { ment authori- } \\
\text { ties (JST) }\end{array}$ & $\begin{array}{l}\text { The individual debt } \\
\text { ratio of JST is deter- } \\
\text { mined so that the } \\
\text { ratio of debt and } \\
\text { interest payment to } \\
\text { total revenues in a } \\
\text { given year must not } \\
\text { exceed the arithme- } \\
\text { tic mean of the three } \\
\text { successive years } \\
\text { prior to a given year, } \\
\text { based on the current } \\
\text { budget and the pro- } \\
\text { ceeds from the sale } \\
\text { of property to total } \\
\text { revenues }\end{array}$ & $\begin{array}{l}\text { Local govern- } \\
\text { ment sector }\end{array}$ & National \\
\hline $\begin{array}{l}\text { The Expendi- } \\
\text { ture Rule }\end{array}$ & $\begin{array}{l}\text { Stabilising Ex- } \\
\text { penditure Rule }\end{array}$ & $\begin{array}{l}\text { Basically, the sector's } \\
\text { expenditure can rise } \\
\text { over a medium-term } \\
\text { GDP real growth } \\
\text { rate multiplied by } \\
\text { CPI* inflation fore- } \\
\text { cast }\end{array}$ & $\begin{array}{l}\text { General govern- } \\
\text { ment sector }\end{array}$ & National \\
\hline $\begin{array}{l}\text { The Revenue } \\
\text { Rule }\end{array}$ & $\begin{array}{l}\text { Obligation to } \\
\text { transfer part } \\
\text { proceeds from } \\
\text { privatisation to } \\
\text { demographic } \\
\text { Reserve Found } \\
\text { (DRF) }\end{array}$ & $\begin{array}{l}\text { DRF receives financ- } \\
\text { ing from, among } \\
\text { others, the trans- } \\
\text { ferred founds from } \\
\text { the privatisation of } \\
\text { State Treasury prop- } \\
\text { erty amounting to } \\
40 \% \text { or the revenue } \\
\text { from the overall } \\
\text { gross amount, minus } \\
\text { obligatory write-offs } \\
\text { towards obligatory } \\
\text { earmarked founds, } \\
\text { obtained from all } \\
\text { privatisation proces- } \\
\text { ses conducted in a } \\
\text { given year }\end{array}$ & $\begin{array}{l}\text { Public finance } \\
\text { sector }\end{array}$ & National \\
\hline
\end{tabular}

* CPI means Consumer Price Index.

Source: Marchewka-Bartkowiak, 2016: 32. 
The important Polish fiscal rule is the constitutional public debt rule, which is one of the main fiscal rules in Polish finance law. According to Polish Constitution: "It shall be neither permissible to contract loans nor provide guarantees and financial sureties which would engender a national public debt exceeding three-fifths of the value of the annual gross domestic product."(Constitution of the Republic of Poland, Art. 216/5) The Polish Ministry of Finance controls if above rule is obeyed.

In the Act on Public Financethe remedial procedureswere also established (PFA, Art. 86-88).They are invoked in case when the public debt exceeds the threshold of 55 and $60 \%$ GDP. The procedures mainly limit the amount of state budget deficit, local authorities' deficit and the possibility of providing new guarantees. When debt-to-GDP-ratio exceed 55 or $60 \%$ the Council of Ministers prepares the recovery program. It shall contain specification of the reasons for the development of the state public debt ratio (i.e. 55 or $60 \% \mathrm{GDP}$ ), a program of measures designed to lead to a lowering of the above mentioned ratio, taking into account the analysis of quantitative limits and other legal circumstances, a three-year forecast concerning the ratio of the state public debt to the gross domestic product along with the predicted macroeconomic developments of the country. The provisions shall not apply in the case of the introduction of a state of emergency, making impossible or significantly hampering the execution of the recovery program.

The Act on Public Finance also established the fiscal rule connected with public expenditures (so called the stabilizing expenditure rule). This fiscal rule was established in PFA, which sets the threshold for the relation to GDP (at levels of 43 and $48 \%$ ). Exceeding these thresholds and fulfillment of additional conditions (defined in PFA) "triggers an automatic correction mechanism that limits the growth rate of expenditure amount for the specific budgetary year" (Ministry of Finance, 2017: 27).

The debt limit concerning the Polish financial law was also determined in reference to the local government units (the so called "individual index of debt"). It is establishedfor every unit, individually, on the basis of a pattern determined in the PFA. Adjustment of this index to the financial possibilities of every unit has two purposes. Firstly, it leadsto the abolition of a strictly-set debt limit in relation to local government units with substantial development potential and creditworthiness. Secondly, local units which are indebted should be disciplined to pay off their liabilities. The construction of debt indexfor local units included, for example,average mean counted on the basis of relation of currentincome units of local government increased by income obtained from the sale ofproperties, 
decreased by the current expenses of the units' income. For calculating thisindex, the data of the last three years is to be taken into account (Justification to the project of PFA, 2009: 39).

The effectiveness of Polish fiscal rules can be illustrated by the amount of public debt and the debt of local government units. Of course, there are others factors which would influence the amount of public and local debt in Poland, such as an economic cycle or economic policy. Anyway, the statistical data can help to examine (even indirectly) the electiveness of fiscal rules in Poland.

The amount of public debt in Poland in the years 2006 - June 2016 is shown in table 3.

Table 3. Public debt in Poland in 2006 - June 2017

\begin{tabular}{|c|c|c|c|c|c|c|}
\hline Item & 2006 & 2007 & 2008 & 2009 & 2010 & 2011 \\
\hline \multicolumn{7}{|c|}{ 1. State Treasury debt } \\
\hline a)PLN bn & 478.5 & 501.5 & 569.9 & 631.5 & 701.9 & 771.1 \\
\hline domestic $^{*}$ & 352.3 & 380.4 & 420.2 & 462.7 & 507.0 & 524.7 \\
\hline foreign * & 126.2 & 121.1 & 149.7 & 168.8 & 194.8 & 246.4 \\
\hline b) GDP $\%$ & $44.7 \%$ & $42.2 \%$ & $44.3 \%$ & $46.0 \%$ & $48.6 \%$ & $49.2 \%$ \\
\hline \multicolumn{7}{|c|}{ 2. Public debt (domestic definition) } \\
\hline a) PLN bn & 506.3 & 527.4 & 597.8 & 669.9 & 747.9 & 815.3 \\
\hline b) GDP $\%$ & $47.3 \%$ & $44.4 \%$ & $46.5 \%$ & $48.8 \%$ & $51.7 \%$ & $52.0 \%$ \\
\hline \multicolumn{7}{|c|}{ 3. General government debt (EU definition) } \\
\hline a) PLN bn & 502.3 & 524.4 & 595.4 & 678.3 & 767.8 & 847.7 \\
\hline b) GDP $\%$ & $46.9 \%$ & $44.2 \%$ & $46.3 \%$ & $49.4 \%$ & $53.1 \%$ & $54.1 \%$ \\
\hline
\end{tabular}

\begin{tabular}{|c|c|c|c|c|c|c|}
\hline Item & 2012 & 2013 & 2014 & 2015 & 2016 & June 2017 \\
\hline \multicolumn{7}{|c|}{ 1. State Treasury debt } \\
\hline a)PLN bn & 793.9 & 838.0 & 779.9 & 834.6 & 928.7 & 945.7 \\
\hline domestic $^{*}$ & 543.0 & 584.3 & 503.1 & 543.3 & 609.2 & 650.2 \\
\hline foreign ${ }^{\star}$ & 250.9 & 253.8 & 276.9 & 291.3 & 319.5 & 295.5 \\
\hline b) GDP $\%$ & $48.7 \%$ & $50.6 \%$ & $45.4 \%$ & $46.4 \%$ & $50.2 \%$ & - \\
\hline \multicolumn{7}{|c|}{ 2. Public debt (domestic definition) } \\
\hline a) PLN bn & 840.5 & 882.3 & 826.8 & 877.3 & 965.2 & 977.2 \\
\hline b) GDP $\%$ & $51.6 \%$ & $53.3 \%$ & $48.1 \%$ & $48.8 \%$ & $52.1 \%$ & - \\
\hline \multicolumn{7}{|c|}{ 3. General government debt (EU definition) } \\
\hline a) PLN bn & 875.3 & 922.8 & 863.9 & 919.6 & $1,006.3$ & $1,016.0$ \\
\hline b) GDP $\%$ & $53.7 \%$ & $55.7 \%$ & $50.2 \%$ & $51.1 \%$ & $54.4 \%$ & - \\
\hline
\end{tabular}

* place of issue criterion

Source: Ministry of Finance, 2017: 49. 
The public debt in Poland in relation to GDP increased from 47,3\% in the year 2006 to $52,1 \%$ in the year 2016. The amount of public debt was under the threshold of $55 \%$ GDP established in PFA in considered period. The amount of general government debt $^{7}$ in relation to GDP was also under the EU debt criterion (60 \% of GDP). It would lead to the consclusion that the fiscal rule could contribute to this process.

The debt of local governmentunits in Poland increasedoverthe last few years. Figure no 1 shows the local government debt in Poland (in the years 2007-2012).

Figure 1. Local government debt in Poland in the years 2007-2012 (in bln euro).

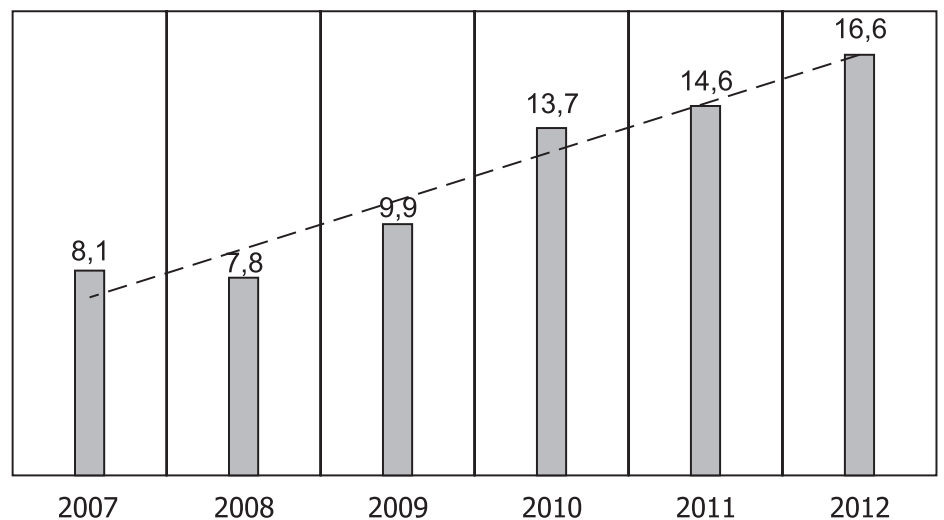

Source: Rae, 2006:105.

The debt of local government units in Poland increased from 8.1 bln euro in the year 2001 to 16.6 bln euro in the year 2012. This is quite high and significant increase. In the year 2001 the share of debt of local government unitsin the Polish public debt was $3.6 \%$. In the year 2011 the share of debt of local government units in public debt increased to $7.9 \%$. So, "the rate of debt growth of local governmentunits and their unions in the years 2001-2011 was far more greater than the growth rate of State Treasury debt(538.6 and $271.6 \%$ respectively)." (Ministry of Finance, 2012a: 54). Problably, one of the reasons of this situation was growing loan needs of local government units. Anyway, this situation improved when the individual debt ratio was introduced. Individual debt ratio is the fical rule concering local government units. In the year 2015 the share of debt of local government units in Polish public debt was $7.8 \%$, and it decreased to $6.8 \%$ in the year 2016 (Ministry of Finance, 2017: 45). It would lead to the conclusion that the above mentioned fiscal rule was effective.

There are differences between public debt (Polish definition) and general goverment debt (EU definition). These differences concern, among others, the scope of public finance sector, and liabilities which constitute public debt (Ministry of Finance, 2017: 45-46). 


\section{Conclusion}

The fiscal rules are the instrument of fical consolidation in EU countries, also in Poland. Moreover, fiscal rules are an example of economization of law.Today financial law establishesthe fiscal rules, which have construction ofeconomic ratios(e.g. debt-to-GDP-ratio). Fiscal rules have supranational (e.g. EU) or national character.

In Polish financial law different kinds of fiscal rules were introduced. At the national level there are fiscal rules such as public debt rule, the stabilising expenditure rule (at level of public finance sector) or the individual debt index (at the level of local government units). Moreover, Poland has to respect the EU supranational fiscal rules such as EU debt citertion (60 \% of GDP) and deficit cirterion (3\% of GDP).

All the above mentioned fiscal rules shoud contribute to limit the amount of public debt in Poland. The statistical data would confirm this hypotesis. The first fiscal rule was established in Poland in the year 1997 (the constitutional debt rule). Then the fiscal rules in PFA was established, among others, the prudential thresholds of public debt (in the year 1998) and the stabilising expenditure rule (in the year 2013). The statistical data concerning the amount of public debt in Poland confirm that public debt did not exceed the Polish and EU debt ratio (debt-to-GDPratio of $60 \%$ of GDP). Both ratios of public debt (Polish definition) and general government debt (EU definition) were under $60 \%$ of GDP. Moreover the debt of local government units also decreased overthe last few years.

Basically, the Polish fiscal rules are evaluated in a positive way. The budget deficit and public debt rules are simple, tranparent and have high legal status (Działo, 2012a). Moreover the Polish fiscal rules "are increasingly complex as they are based on legally binding mathematic and econometric formulas" (Marchewka-Bartkowiak, 2016: 35).

Taking into account the above mentioned considerations the hypothesis of this paper may be partially confirmed. The fiscal rules established in the Polish financial law were effective in limiting public debt. Nevertheless, it is difficult to examine its impactprecisely.

\section{References}

Buiter, W.: The commandments for a fiscal rule in E(M)UM, London, 2003, http://citeseerx.ist.psu.edu/viewdoc/download?doi=10.1.1.201.8395\&rep=rep1\&type=pdf. 
Bukowski, M. et al: Struktura i poziom wydatków i dochodów sektora finansów publicznych a sytuacja na rynku pracy. Doświadczenia międzynarodowe i wnioski dla Polski (Structure and Level of Expenditures and Revenues of the Sector of Public Finances and the Situation at the Labour Market. International Experiences and Conclusions for Poland), Warsaw: National Bank of Poland, 2005.

Buti, M., Guidice, G.: EMU's fiscal rules: what can and cannot be exported, European Commission, 2002, https://www.researchgate.net/publication/229007051_EMU\%27s_fiscal_rules_What_can_and_cannot_be_exported.

Działo, J.: Fiscal Rules and Effective Fiscal Policy, Comparative Economic Research, no. 2 (2012a).

Działo, J.: Ocena skuteczności reguł fiskalnych w Polsce (the Evaluation of Effectiveness of Fiscal Rules in Poland), Studia Prawno-Ekonomiczne (Legal and Economic Studies) vol. LXXXV (2012b).

Gaudemet, P., Moliner, J.: Finanse publiczne (Public Finance), Warsaw: PWE Publishing, 2000.

Gupta, S. et al: Expenditure Composition, Fiscal Adjustment, and Growth in Low - Income Countries, IMF Working Paper no. 77 (2002).

Kopits, G., Symansky, S.: Fiscal Policy Rules, IMF, Occasional Paper no. 162 (1998).

Kosikowski, C.: Finanse publiczne i prawo finansowe (Public finance and finance law), Warsaw: WSPiZ Publishing, 2001.

Krajewski, P. et al: The Optimal Fiscal Rule in the Context of Accession to the Eurozone, Economic Research, Ekonomska Istraživanja (Economical News) vol. 28, no. 1 (2015), http://dx.doi.org/10.1080/1331677X.2015.1041779.

Marchewka-Bartkowiak, K.: Numerical Fiscal Rules - The Experience of Poland, Zeszyty Naukowe Wyższej Szkoły Bankowej w Poznaniu (Reaserch Papers of WSB Universities) vol. 70, no. 5 (2016).

Marchewka-Bartkowiak, K.: Reguły fiskalne (Fiscal Rules), Analyses of the Bureau of Research of Sejm no. 7 (2010).

Nizioł, K.: Fiscal Rules as an Instrument of Fiscal Consolidation (Chosen Issues), Bocconi Legal Paper (2013), https://works.bepress.com/bocconi_legal_papers/47/.

Nizioł, K.: Prawne aspekty długu publicznego (The legal Aspects of Public Debt), Szczecin: Polgres Publishing, 2013.

Oręziak, L.: Finanse Unii Europejskiej (European Union Finances), Warsaw: PWN Publishing, 2005.

Public Debt in Poland. Annual Report, Warsaw: Ministry of Finance, 2012.

Public Debt in Poland. Annual Report, Warsaw: Ministry of Finance, 2017.

Rae, G.: Public Debt and Its Impact on the Polish Economy and Society, Journal of Management and Business Administration. Central Europe vol. 24, no. 1 (2016).

Rybarski, R.: Nauka skarbowości (The science of Finance), Warsaw: F. Wyszyński i Sp. Publishing, 1935. 
Sutherland, D. et al: Fiscal consolidation: Howz much, how fast and by what means?, OECD Economic Policy Papers no. 1 (2012).

The OECD Economic Outlook: Sources and Methods, OECD, 2001. http://statp.oecd. org/glossary/detail.asp?ID=984.

The Public finance sector debt management strategy in the years 2018-2021, Warsaw: Ministry of Finance, 2017.

\section{Legal Acts}

Constitution of the Republic of Poland, 1997, as amended.

Treaty on the Functioning of the European Union, as amended.

Regulation (EU) no. 1176/2011 of the European Parliament and of the Council on the Prevention and Correction of macroeconomic imbalances.

Regulation (EU) no. 1174/2011 of the European Parliament and of the Council on Enforcement Measures to Correct Excessive Macroeconomic Imbalances in the Euro Area.

Council Regulation (EU) no. 1466/97 on the Strengthening of the Surveillance of Budgetary Positions and the Surveillance and Coordination of Economic Policies.

Act of 2009, on Public Finance, as amended.

Justification to the project of the Act on Public Finances (parliamentary printed matter no. 1181 (2009), http://orka.sejm.gov.pl/Druki6ka.nsf/wgdruku/1181. 
